\title{
Purification and Properties of a New Virus from Black Currant, Its Affinities with Nepoviruses, and Its Close Association with Black Currant Reversion Disease
}

\author{
A. Lemmetty, S. Latvala, A. T. Jones, P. Susi, W. J. McGavin, and K. Lehto
}

\begin{abstract}
First and second authors: Agricultural Research Centre, Institute of Plant Protection, FIN-31600 Jokioinen, Finland; second and sixth authors: Department of Biology, Laboratory of Plant Physiology and Molecular Biology, University of Turku, FIN-20520 Turku, Finland; third and fifth authors: Scottish Crop Research Institute, Invergowrie, Dundee DD2 5DA, Scotland; and fourth author: Department of Plant Production, University of Helsinki, FIN-00014 Helsinki, Finland.
\end{abstract}

Accepted for publication 16 December 1996.

\begin{abstract}
Lemmetty, A., Latvala, S., Jones, A. T., Susi, P., McGavin, W. J., and Lehto, K. 1997. Purification and properties of a new virus from black currant, its affinities with nepoviruses, and its close association with black currant reversion disease. Phytopathology 87:404-413.

Black currant reversion is a virus-like disease whose causal agent has not been identified. In rooted cuttings of a black currant plant affected with the severe form of the disease, pronounced chlorotic line patterns and ringspots developed in newly emerging leaves. From such symptombearing leaves, a virus was mechanically transmitted with difficulty to Chenopodium quinoa and, from this host, to other herbaceous test plants. The virus was purified and partially characterized, and the purified virions were used for antiserum production. Virus particles were isometric, approximately $27 \mathrm{~nm}$ in diameter, and sedimented as two nucleoprotein components. They contained a protein species with a molecular mass of $55 \mathrm{kDa}$, which was readily degraded into a $54-\mathrm{kDa}$ protein and two major RNA components of about 6,700 and 7,700 nucleotides (nt), each with a poly(A) tail. Most of these properties are shared by nepoviruses, but the

ruses tested. However, the deduced sequence of 1,260 nt at the $3^{\prime}$ end of one of the viral RNA species was distinct from any known viral sequence, except that it contained short regions of homology to the $3^{\prime}$ terminal sequences of RNAs of seven other nepoviruses and two comoviruses. To detect this virus in Ribes plants, primers were designed from the known sequence to amplify a 210-nt region of the cDNA of the virus RNA using an immunocapture reverse transcriptase polymerase chain reaction (IC-RT-PCR) protocol. Using this assay for the virus, we associated its presence with two recognized forms of black currant reversion disease occurring in Finland, Scotland, or New Zealand. We also detected the virus in vector gall mites from reverted plants and in black currant plants on which such vector mites had fed. However, the virus was not detected by IC-RT-PCR in known healthy Ribes plants; in Ribes plants free from reversion, but affected by three other distinct virus-like diseases of Ribes; or in plants infected with arabis mosaic, strawberry latent ringspot, or raspberry ringspot nepoviruses. These data suggest that this virus may be the causal agent of reversion disease, and it is tentatively called black currant reversion associated virus.
\end{abstract} virus was serologically unrelated to 14 nepoviruses or putative nepovi-
Black currant reversion is a virus-like disease, the agent of which is transmitted in nature by the eriophyid gall mite (Cecidophyopsis ribis Westwood) and experimentally by graft inoculation. The disease has been reported from all countries where black currant (Ribes nigrum L.) is grown commercially, with the exception of the Americas $(1,12)$. The disease occurs in at least two forms, the common (European, E) (12) form and a more severe (Russian, R) (12) form that seems restricted in its natural distribution to countries of the former Soviet Union, Eastern and Central Europe, and Scandinavia $(1,4,5,12,26)$. Symptoms of the disease are characterized by varying intensities of leaf malformations, suggestive of a reversion to a primitive wild plant form. Compared with leaves of healthy plants, those of reverted plants are narrower, show a decreased number of main veins, have larger but fewer marginal serrations, and have a basal sinus that is less lobed. These symptoms are usually more pronounced in the $\mathrm{R}$ than in the $\mathrm{E}$ form of the disease, but symptoms vary in intensity between black currant cultivars (12). Another consistent symptom of the disease, seen only in newly emerging flower buds, is a brighter pigmentation of the buds compared with those of healthy plants due to a loss of the downy hairs on buds (1). On plants af-

Corresponding author: K. Lehto; E-mail address: klehto@utu.fi

Publication no. P-1997-0214-01R

(C) 1997 The American Phytopathological Society fected by the $\mathrm{R}$ form of the disease, flower buds also develop strong malformations including the absence of stamens, elongation of the style, and an increase in the number of petals; pigmentation is also intensified further. Affected flower buds in both forms of the disease are usually sterile, causing a severe loss in fruit productivity. Less consistent in appearance is the development in spring of foliar chlorotic line patterns and ringspots, alone or in combination, that occur in a few black currant cultivars that are affected by either form of the disease $(1,12)$, but the expression of this symptom seems to be dependent on genotype/environment interactions that are not well studied. The leaf markings usually become less obvious as the leaves age and are not evident on new growth during the summer. However, the line-pattern symptoms are not diagnostic of reversion, as similar symptoms can be induced in black currant by infection with some nepoviruses, cucumber mosaic cucumovirus, and alfalfa mosaic virus $(1,12,13)$.

The causal agent of reversion disease remains uncharacterized despite the research efforts made over more than 50 years. Graft inoculation to sensitive black currant cultivars remains the only test for its detection, but symptom development requires up to 2 years $(1,11)$. Previous reports that the disease agent was a mycoplasma-like organism (19) and potato Y potyvirus (9) have not been confirmed (1). In this paper, we report the isolation and partial characterization of a new virus that was sap-transmitted with difficulty from a rooted cutting of a black currant plant affected with the $\mathrm{R}$ form of the disease. The virus shares several physico- 
chemical properties with members of the proposed subgroup 3 of nepoviruses $(15,16)$, but is distinct from members or possible members of this subgroup and from any other nepoviruses.

An immunocapture reverse transcriptase polymerase chain reaction (IC-RT-PCR) protocol was developed to detect the virus in Ribes plants and, using this detection method, the occurrence of this virus in Ribes plants was found to be very closely associated with black currant reversion disease infection. Because of this close association, we refer to the virus as black currant reversion associated virus (BRAV).

\section{MATERIALS AND METHODS}

Plant material, inoculation methods, and virus culture. Black currant bushes of a Scottish Crop Research Institute (SCRI) breeding line, P9/5/1, growing at the experimental field of the Agricultural Research Centre, Institute of Horticulture (ARC-IH), Piikkiö, Finland, had shown distinctive floral and leaf symptoms of the R form of reversion since 1987. In June 1990, cuttings were taken from the plants and rooted in a peat-sand mixture in a glasshouse of the Agricultural Research Centre, Institute of Plant Protection (ARC-IPP), Jokioinen, Finland. Symptomatic leaves of rooted black currant cuttings were ground in $2 \%$ nicotine solution, $\mathrm{pH}$ 9.5, the extract rubbed on Carborundum-dusted leaves of herbaceous test plants, and the plants maintained in a glasshouse at about $21^{\circ} \mathrm{C}$. Following one of these inoculations, symptoms were observed in one Chenopodium quinoa Willd. plant.

Subsequent mechanical transfer from $C$. quinoa to a range of herbaceous test plants was done by extracting sap in $50 \mathrm{mM}$ phosphate buffer, $\mathrm{pH} 7.0$, or water. The virus was maintained by serial passages in $C$. quinoa and other herbaceous hosts and was also preserved as infected $C$. quinoa leaves at -20 and $-80^{\circ} \mathrm{C}$.

Virion purification. Inoculated and systemically infected leaves of $C$. quinoa were harvested 15 to 21 days after inoculation. BRAV was purified using a slight modification of the method described by Frison and Stace-Smith (8) for arabis mosaic nepovirus. In other experiments, BRAV was purified from Nicotiana benthamiana Domin. plants by clarifying the plant extracts with $50 \%$ ( vol/vol) chloroform. The aqueous phase was further clarified and concentrated by one cycle of high and low speed centrifugation. Centrifugation in 10 to $40 \%$ sucrose density gradient in $0.05 \mathrm{M}$ citrate buffer, $\mathrm{pH} 7.0$, was used as the final purification step. The pellets were resuspended in a small volume of citrate buffer, $\mathrm{pH}$ 7.0.

Serological tests. New Zealand white rabbits were immunized subcutaneously with about 50 to $100 \mu \mathrm{g}$ of purified virions in Freund's incomplete adjuvant. Two booster injections were administered intramuscularly at 14-day intervals, and the animals were bled 14 days after the last injection. The sera were stored at $-20^{\circ} \mathrm{C}$. Gel double diffusion serological (Ouchterlony) tests were done in $1 \%$ agarose gels in phosphate-buffered saline (PBS), $\mathrm{pH}$ 7.0. In enzyme-linked immunosorbent assay (ELISA) for cherry leaf roll nepovirus, a commercial kit (Loewe Biochemica GmbH, Sauerlach, Germany) was used according to the manufacturer's instructions. Other virus antisera used were from the collection held at SCRI, Scotland, or were acquired as gifts from scientists elsewhere.

Electron microscopy. Purified virion preparations were placed on carbon-coated copper grids and negatively stained with $2 \%$ ammonium molybdate, $\mathrm{pH} 7.0 ; 1.5 \%$ phosphotungstate (PTA), $\mathrm{pH}$ 7.0; $2 \%$ methylamine tungstate, $\mathrm{pH} 7.0$; or $2 \%$ uranyl acetate, $\mathrm{pH}$ 3.5. The grids were examined in a JEOL JEM-100SX or JEOL $100 \mathrm{~S}$ electron microscope (JOEL, Ltd., London).

Analysis of the virus coat protein and nucleic acid. The size of the viral coat protein was determined by electrophoresis of sodium dodecyl sulfate (SDS)-boiled virions in 10\% SDS-polyacrylamide gel electrophoresis (PAGE) gels as described by Laemmli (14). Nucleic acid was isolated from purified virus preparations by using either the commercial Micro-FastTrack kit (Invitrogen Corp., San Diego, CA) for isolation of poly(A)-tailed RNA or by extraction with phenol, phenol-chloroform, and precipitation with ethanol. The extracted nucleic acid was denatured with glyoxal and dimethyl sulfoxide, analyzed in $1 \%$ agarose gels, and stained with ethidium bromide as described by Sambrook et al. (23).

For Northern blot analysis, the RNAs were transferred from agarose gels to Hybond-N membrane (Amersham, Buckinghamshire, United Kingdom), and the membrane was fixed by UV light and deglyoxylated by baking at $80^{\circ} \mathrm{C}$ for $2 \mathrm{~h}$. The blots were probed with digoxygenin-dUTP- (Boehringer Mannheim, Mannheim, Germany) labeled virus cDNA. Hybridization reactions were detected using the DIG luminescent detection kit (Boehringer Mannheim).

cDNA cloning and sequence analysis. To a 300- $\mu$ l volume of purified virion suspension (approximately $0.05 \mathrm{mg}$ ), an equal volume of RNA extraction buffer $(0.1 \mathrm{M}$ glycine, $0.1 \mathrm{M}$ Tris $[\mathrm{pH}$ 8.6], $0.1 \mathrm{M} \mathrm{NaCl}, 0.01 \mathrm{M}$ EDTA, $0.2 \% \mathrm{SDS}$, and $0.2 \%$ sodium dodecyl sarcosine [pH 8.6]) was added. RNA was extracted from this suspension by adding an equal volume of phenol/chloroform and the RNA ethanol precipitated. First-strand cDNA from the viral RNA was synthesized with oligo-dT primers using the firststrand cDNA synthesis kit (Pharmacia Biotechnology Inc., Uppsala, Sweden). The reaction mix was used directly for secondstrand synthesis according to Sambrook et al. (23). NotI-linkers were added to the cDNA, which was then ligated into the NotIdigested, dephosphorylated Bluescript $\mathrm{SK}+$ vector and transformed by electroporation into JM109 cells. From selected recombinant clones, DNA was isolated by alkaline lysis (23) either in minipreparation scale for preliminary restriction analysis or in large scale for sequence analysis. The sequence analysis was performed by automated sequencing using the ALF Manager system, version 2.5 (Pharmacia Bioechnology Inc.). The sequence data was analyzed using various programs in the Wisconsin Sequence Analysis Package, version 8.0 (Genetic Computer Group, Madison, WI), as indicated in the results.

Design of oligonucleotide primers. Based on the known sequence for the $3^{\prime}$ end of BRAV, the following oligonucleotides were synthesized: 5' GAAAGGACATTTCAG 3' (primer 1), complementary to the viral nucleotide sequence in positions 1 to 15 upstream of the poly(A) tail, and 5' CGCTGGTGTCTC 3' (primer 2), identical to viral nucleotide sequence in positions 198 to 210 upstream of the poly(A) tail. The primers were synthesized by the solid phase phosphoramidite method in 0.01- mol scale and desalted before use.

IC-RT-PCR protocol. Immunocapture of BRAV particles from leaf and mite extracts essentially followed the method of Nolasco et al. (18) with minor modifications. Leaves $(0.3 \mathrm{~g})$ were powdered in liquid $\mathrm{N}_{2}$ with a pestle and mortar, and $2.1 \mathrm{ml}$ of cold Tris-EDTA buffer (10 mM Tris-HCl, $\mathrm{pH} \mathrm{8,} \mathrm{and} 1 \mathrm{mM}$ EDTA, $\mathrm{pH}$ 8 ) were added. About $0.5 \mathrm{ml}$ of the extract was transferred to an Eppendorf tube, frozen at $-20^{\circ} \mathrm{C}$ for $20 \mathrm{~min}$, thawed, and centrifuged for $5 \mathrm{~min}$ at $3,000 \mathrm{rpm}(650 \times \mathrm{g})$ at $4^{\circ} \mathrm{C}$. An aliquot $(50 \mu \mathrm{l})$ of the clear supernatant was then added to PCR tubes previously incubated with $50 \mu \mathrm{l}$ of a 1:150 dilution of virus antiserum in 50 $\mathrm{mM}$ sodium carbonate, $\mathrm{pH} 9.6$, at $37^{\circ} \mathrm{C}$ for $2 \mathrm{~h}$ and subsequently washed twice with $100 \mu \mathrm{l}$ of PBS containing $0.05 \%$ Tween 20 (PBS-Tween). After the addition of the clarified plant extracts to the coated PCR tubes, the tubes were incubated at $37^{\circ} \mathrm{C}$ for $4 \mathrm{~h}$ or at $7^{\circ} \mathrm{C}$ overnight. After incubation, the PCR tubes were emptied, washed twice with $100 \mu \mathrm{l}$ of PBS-Tween, $8 \mu \mathrm{l}$ of water was added, and the tubes were heated at $65^{\circ} \mathrm{C}$ for $10 \mathrm{~min}$ to disrupt the trapped virus particles. The tubes were placed on ice and used directly for the first-strand synthesis using oligonucleotide primer 1 and the first-strand cDNA synthesis kit (Pharmacia Biotechnology Inc.). The reaction mixture contained $8 \mu \mathrm{l}$ of RNA in water, $1 \mu \mathrm{l}$ of primer 1 (40 pmol), $1 \mu \mathrm{l}$ of $200 \mathrm{mM}$ dithiothreitol, and $5 \mu \mathrm{l}$ of reverse transcription mixture (Pharmacia Biotechnology 
Inc.). The reactions were incubated at $37^{\circ} \mathrm{C}$ for $1 \mathrm{~h}$ and then at $90^{\circ} \mathrm{C}$ for $5 \mathrm{~min}$ to inactivate the reverse transcriptase. For PCR, the "hot start" method (7) was used. The PCR reaction components were pipetted into the PCR tubes before the addition of the cDNA samples. The reaction mixture $(50 \mu \mathrm{l})$ contained 20 to 40 pmol of primers 1 and 2 and $400 \mu \mathrm{M}$ of the dNTPs (Pharmacia Biotechnology Inc.) in $1 \times$ DyNAzyme DNA polymerase buffer (Finnzymes Oy, Espoo Finland). The reaction mixture was covered with melted DyNAWax (Finnzymes Oy), which quickly solidified on contact with the reaction mixture. On top of this wax layer was added $50 \mu$ of a solution containing $2 \mathrm{U}$ of DyNAzyme DNA polymerase (Finnzymes Oy) and $5 \mu \mathrm{l}$ of the first-strand cDNA reaction in $1 \times$ DyNAzyme polymerase buffer (Finnzymes Oy). PCR amplification was in a Omnigene thermal cycler (Hybaid Ltd., Teddington, Middlesex, United Kingdom) with 30 cycles of template denaturation at $95^{\circ} \mathrm{C}$ for $1 \mathrm{~min}$, primer annealing at $37^{\circ} \mathrm{C}$ for $1 \mathrm{~min}$, and elongation at $72^{\circ} \mathrm{C}$ for $1 \mathrm{~min}$. After 30 cycles, the products were elongated at $72^{\circ} \mathrm{C}$ for $10 \mathrm{~min}$ and cooled to $4^{\circ} \mathrm{C}$. Aliquots $(30 \mu \mathrm{l})$ of the PCR reactions were electrophoresed in 1.5 or $2 \%$ agarose gels in $1 \times$ Tris-acetate-EDTA buffer (40 mM Tris-acetate and $1 \mathrm{mM}$ EDTA, pH 8.0), and the gels were stained with ethidium bromide and viewed under UV light.

Plant samples for analysis. Plant samples for PCR analysis were collected in late spring/early summer 1994 and 1995. In Finland, samples were from field plants showing flower and leaf symptoms of reversion disease from the ARC-IPP. Healthy plants (virus tested by graft inoculation) were originally from the Laukaa Research and Elite Plant Unit of the Agricultural Research Centre of Finland and subsequently maintained in a protected glasshouse at ARC-IPP. In Scotland, samples were from certified virus-tested mother plants maintained in a protected screen house at SCRI, Dundee, and indexed regularly to establish their continued freedom from all known virus diseases of Ribes and from these and other such plants infected previously by grafting with known viruses or virus-like agents or infested with eriophyid gall mites from reverted black currant bushes. Samples from New Zealand were of healthy and reverted black currant cv. Silvergiertes

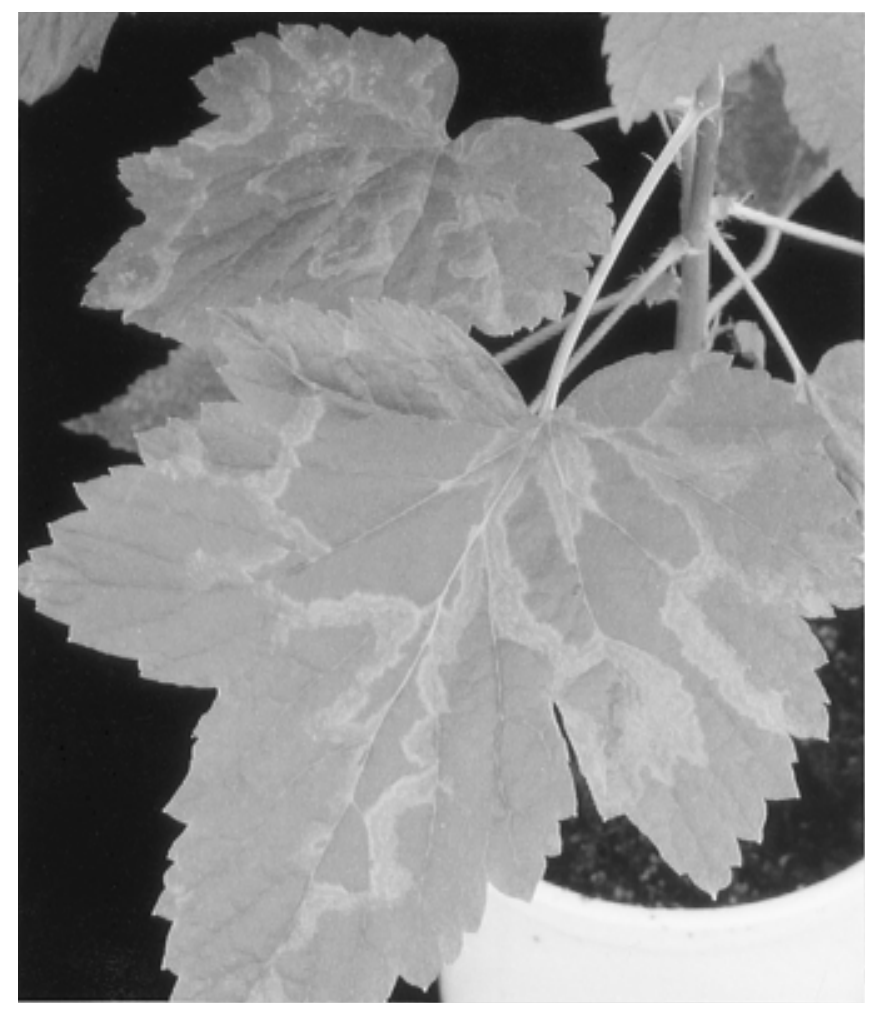

Fig. 1. Conspicuous chlorotic line patterns on the leaves of reverted black currant selection Scottish Crop Research Institute P9/5/1 after rooting.
Schwarze. The reverted samples showed either mild or severe symptoms of the $\mathrm{E}$ form of the disease. Samples of nepoviruses in C. quinoa were from cultures maintained at SCRI.

\section{RESULTS}

Mechanical transmission of BRAV to herbaceous hosts from the reverted black currant line SCRI P9/5/1. During rooting of soft wood cuttings from the reverted black currant breeding line SCRI P9/5/1, severe chlorotic, yellow line patterns and ringspots developed in the expanding leaves (Fig. 1). Similar leaf symptoms, though less severe, were also observed in rooted cuttings of the black currant cvs. Öjebyn, Parikkala, and Lepaan Musta affected with the $\mathrm{R}$ form of reversion.

Repeated attempts were made to mechanically transmit an agent from these symptom-bearing leaves, but, in more than 20 separate attempts, virus was transmitted on only one occasion. In this instance, 7 days after inoculation, a few distinct pinpoint chlorotic/ necrotic lesions developed in the inoculated leaves of one $C$. quinoa plant (Fig. 2A) followed about 1 week later by systemic chlorotic or necrotic flecking (Fig. 2B) and malformation of leaves. No symptoms developed in Petunia hybrida Vilm. cv. Resisto Moerkrosa and N. glutinosa L. plants inoculated with the same inoculum. Attempted mechanical transmissions from rooted cuttings of other black currant cultivars affected with the $\mathrm{R}$ form of reversion and also from gall mites collected from the galled buds of these reverted bushes were unsuccessful.

Host range and symptomatology in herbaceous plants. Sap from symptom-bearing leaves of $C$. quinoa, and later from $N$. benthamiana, was rubbed onto a range of herbaceous plants. The following plant species were infected (symptoms described in parenthesis): C. amaranticolor Coste \& Reyn. (many pinpoint necrotic local lesions in 6 to 8 days; usually not systemic); $C$. murale L. (necrotic local lesions in 6 to 8 days followed occasionally by systemic necrotic spots 4 to 6 days later); $N$. benthamiana (systemic vein clearing/yellowing in 8 to 11 days [Fig. 2C]); $N$. clevelandii Gray (occasional necrotic local lesions in 7 to 8 days); $N$. debnyi Domin. (occasional faint large chlorotic local lesions); N. occidentalis Wheeler, accession 37-B (local necrotic lesions and rings in 6 to 8 days [Fig. 2D]); N. occidentalis ssp. obligua, accession P-1 (local necrotic lesions and rings in 6 to 8 days).

The following species were symptomlessly infected as assessed by back inoculations to $C$. quinoa (asterisks indicate those species in which BRAV infected plants only locally): Cucumis sativus L. cv. National Pickling, Datura stramonium L., Lycopersicon esculentum Mill. cv. Moneymaker, N. glutinosa*, N. rustica L., N. tabacum L.* cv. Samsun NN, Petunia hybrida* cv. Blue Picotee, and Spinacia oleracea L. The following species were not infected: Gomphrena globosa L., Phaseolus vulgaris L. cv. The Prince, Physalis floridana Rybd., and Tetragonia expansa Murr.

Virus properties in plant sap. When assayed to $C$. quinoa plants, BRAV lost infectivity in sap of infected $N$. benthamiana after diluting $10^{-2}$ to $10^{-3}$, storage for more than 1 day at $20^{\circ} \mathrm{C}$, and 4 to 8 days at either 4 or $-15^{\circ} \mathrm{C}$. More than $50 \%$ of BRAV infectivity was lost within 6 to $7 \mathrm{~h}$ of extraction from $N$. benthamiana sap kept at room temperature. Infectivity was stabilized by the addition of $0.2 \%$ thioglycerol to extracted sap, but not by the addition of $5 \mathrm{mM}$ sodium diethyl dithiocarbamate or $5 \mathrm{mM}$ EDTA.

Properties of purified virion preparations. During early spring and summer (May to July), BRAV symptoms in C. quinoa diminished and the yield was very low. Yields of virus were relatively small even when preparations were made at the optimum time of year for symptom expression. Yields of the virus were 0.5 to $5 \mathrm{mg} / \mathrm{kg}$ of leaf. Following sucrose density gradient centrifugation, purified virion preparations usually formed two closely sedimenting light-scattering bands that were identified with the two main peaks of absorbance in the middle of the gradient (Fig. 3). 
Electron microscopy. In the electron microscope, virion preparations contained many isometric particles, some with angular (icosahedral) outlines, and measured about $27 \mathrm{~nm}$ in diameter (Fig. 4). Many particles were penetrated by all four negative stains used, but the proportion of particles penetrated by stain appeared greater in ammonium molybdate, $\mathrm{pH} 7.0$, than in PTA, $\mathrm{pH} 7.0$, methylamine tungstate, $\mathrm{pH} 7.0$, or uranyl acetate, $\mathrm{pH} 3.5$. In uranyl acetate, those particles partially penetrated by the stain appeared to have either a central core or a thicker protein shell that was not evident in particles in the other stains (Fig. 4A and B). Whilst these differences in particle appearance may be artifacts caused by the uranyl acetate stain, they have not been observed previously for particles of definitive nepoviruses in this stain.
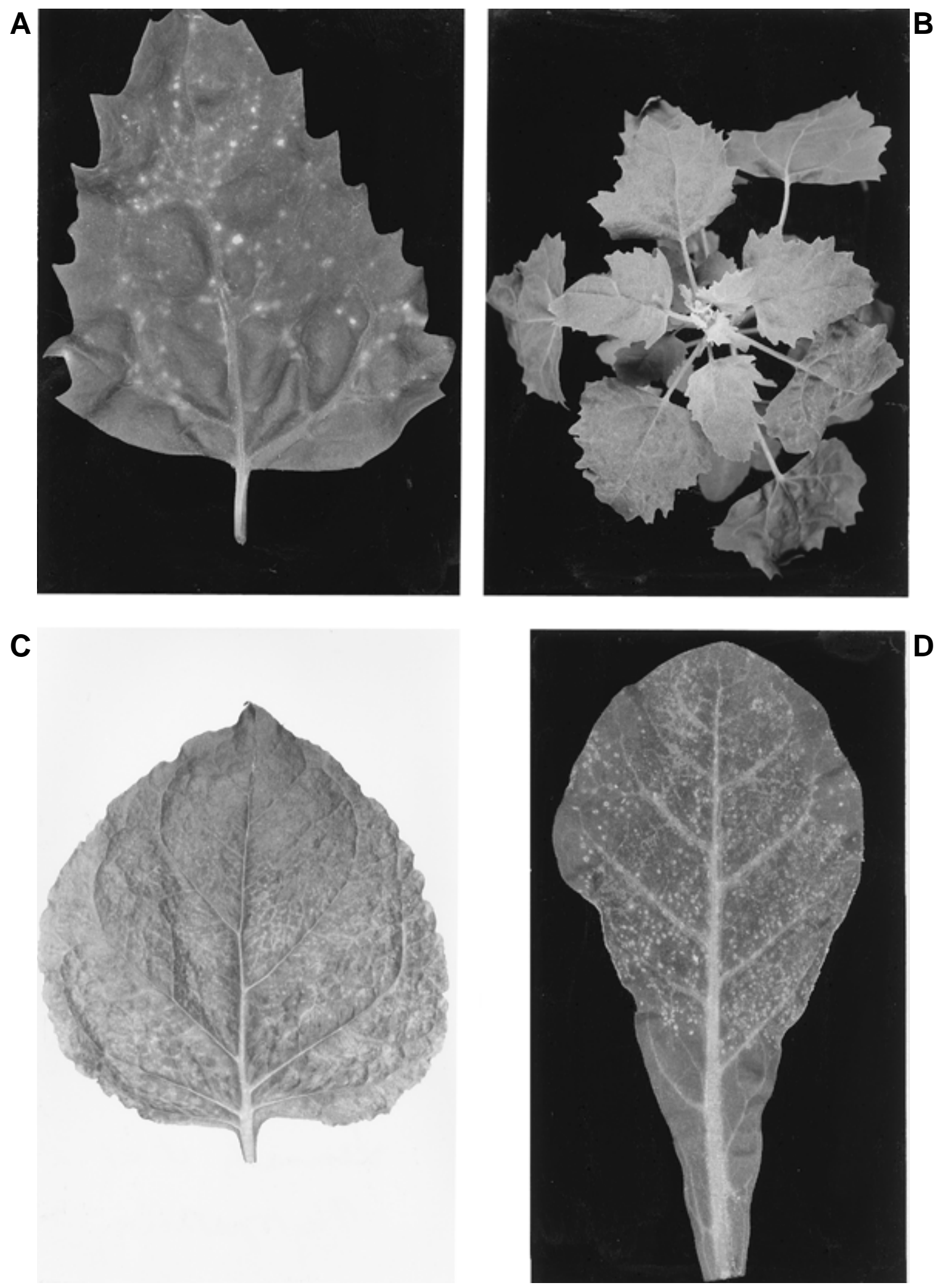

Fig. 2. Symptoms induced in leaves of herbaceous test plants following mechanical inoculation with black currant reversion associated virus, using extracts from Chenopodium quinoa. A, Necrotic local lesions in C. quinoa 1 week after inoculation. B, Systemic chlorotic flecking in $C$. quinoa 2 weeks after inoculation. C, Systemic vein clearing in Nicotiana benthamiana 10 days after inoculation. D, Necrotic local lesions in N. occidentalis 37-B 8 days after inoculation. 
Serological tests. In agarose gel double diffusion tests, the antiserum to BRAV had an homologous titer of $1 / 16$ and a titer to healthy $C$. quinoa of $>1 / 8$. Because the properties of BRAV indicated similarities with nepoviruses, especially those of the proposed subgroup $3(15,16)$, and because several nepoviruses have been reported infecting Ribes, serological tests were made using a range of nepoviruses and nepovirus antisera. In gel double diffusion tests using antiserum to BRAV at a dilution of $1 / 8$, no reaction was detected to the following nepoviruses in sap of infected C. quinoa: arabis mosaic (ArMV, strain $\mathrm{S}$ ), cherry leaf roll (CLRV, strains B, C, and G) (10), grapevine fanleaf (GFLV), raspberry ringspot (RpRSV, strains $\mathrm{E}$ and $\mathrm{S})$, strawberry latent ringspot (SLRSV, strain S), tomato black ring (TBRV, strains E

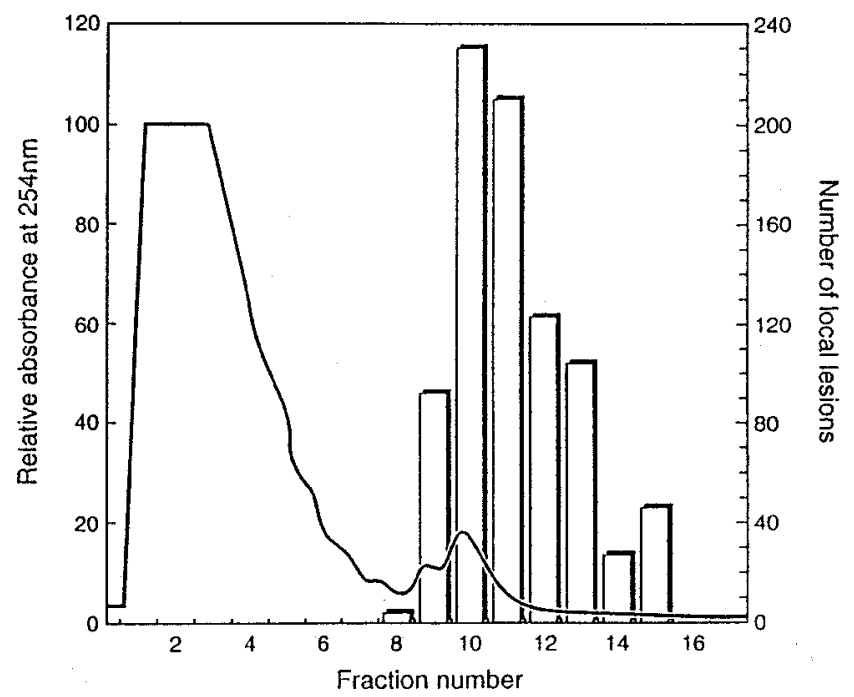

Fig. 3. UV absorbency profile (solid line) at $A_{254}$ of 12-drop fractions of a partially purified preparation of black currant reversion associated virus following sucrose density gradient centrifugation for $135 \mathrm{~min}$ at 35,000 rpm in Beckman SW40.1 tubes (Beckman Instruments, Inc., Irvine, CA). Bars indicate the relative numbers of local lesions in Chenopodium quinoa leaves of diluted fractions. and S) and tomato ring spot (ToRSV, strains AYB, PSP, and PBL). In reciprocal tests, purified preparations of BRAV failed to react specifically with antiserum (diluted 1/16) to the following nepoviruses (virus strain and homologous titers, when known, are given in parenthesis): $\operatorname{ArMV}(\mathrm{S}, 1 / 1,024)$, artichoke yellow ringspot (AYRSV, 1/32), blueberry leaf mottle (BLMV, 1/512), cassava green mottle (CGMV), CLRV (C, 1/128; G, 1/1,024; R, 1/64), chicory yellow mottle (ChYMV, 1/512), grapevine Bulgarian latent (GBLV, 1/512), GFLV (1/512), lucerne Australian latent (LALV, 1/256), hibiscus latent ringspot (HLRSV, 1/4,000), peach rosette mosaic (PRMV, 1/1,024), RpRSV (S; E, 1/512), SLRSV (S, 1/2,048), TBRV (E, 1/1,024; S, 1/8,192), and ToRSV (Chickadee, Elderberry, and West Virginia). In further tests with CLRV, double-antibody sandwich (DAS)-ELISA (Loewe Biochemica commercial kit, unidentified isolate; Loewe Biochemica $\mathrm{GmbH}$ ) detected no reaction to BRAV either in sap of infected $C$. quinoa leaves or as purified virions.

Analysis of viral protein and RNA. When analyzed by SDSPAGE, protein extracts of purified virion preparations usually migrated as two clearly defined bands of 54 and $55 \mathrm{kDa}$ (Fig. 5). However, in some preparations, only the $54-\mathrm{kDa}$ virus protein band was detected (Fig. 5, lane d). When the virus preparation from which only this protein was derived was inoculated to $C$. quinoa, it produced symptoms identical to the BRAV initial infection, and a purified virus particle preparation from such infected plants contained both the 54- and 55-kDa proteins. This suggests that both proteins are derived from the virus and that the smaller one probably occurs as a result of limited proteolysis of the larger one as has been reported for TBRV (6). These two protein bands were consistently observed in Western blots of purified BRAV preparations when analyzed with a BRAV polyclonal antiserum (data not shown).

When analyzed on denaturing agarose gels, the virus nucleic acid preparations produced two major bands. The nucleic acid profiles from samples obtained either by absorption to commercial oligo-dT cellulose matrix (Invitrogen Corp.) or by phenol extraction and ethanol precipitation were identical (data not shown). The addition of $10 \mu \mathrm{g} / \mathrm{ml}$ of RNase A in the preparations totally abolished nucleic acid detection, indicating that the virus nucleic acid
A

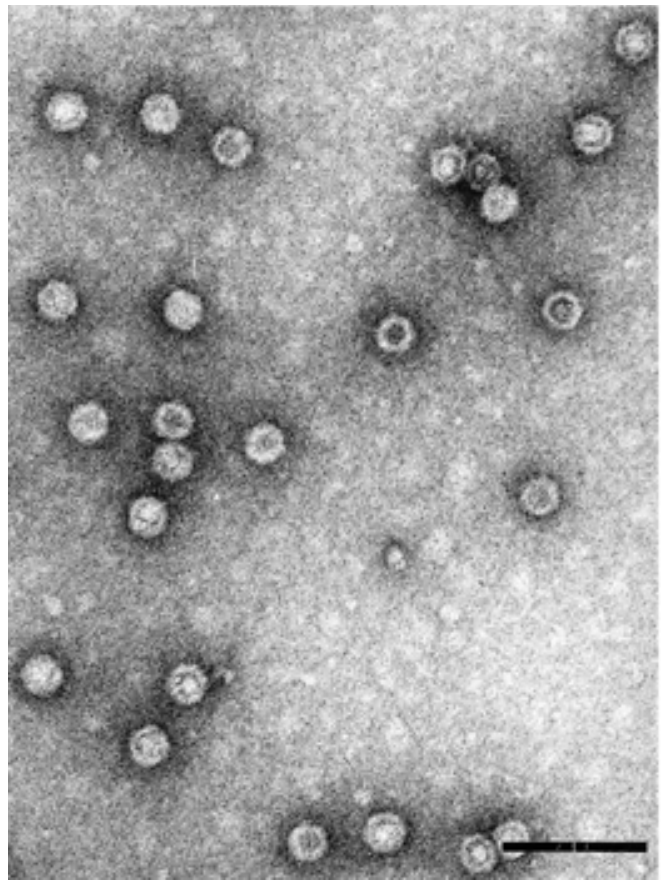

B

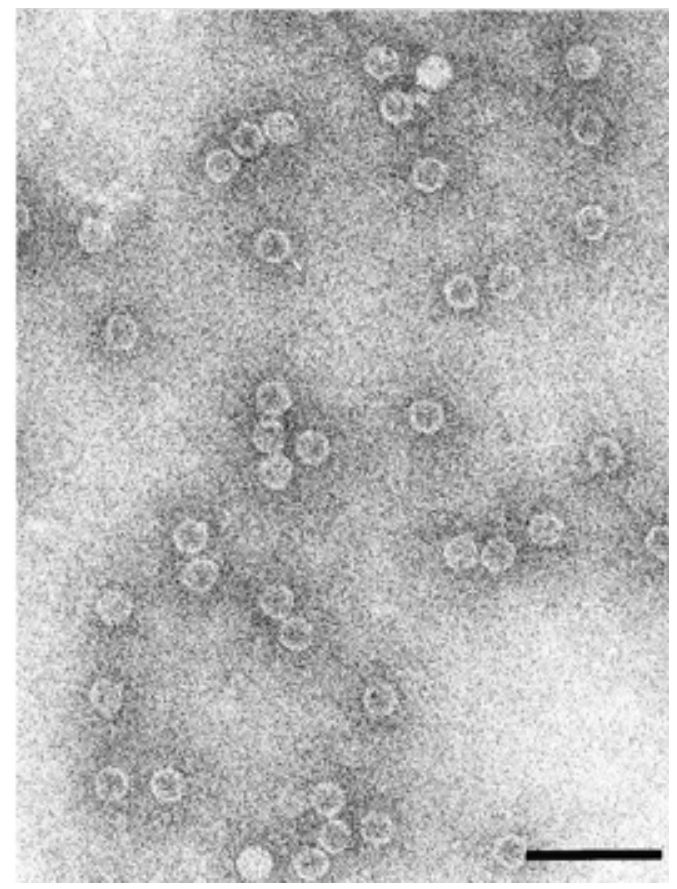

Fig. 4. Electron micrographs of purified black currant reversion associated virus preparation stained with A, uranyl acetate, $\mathrm{pH} 3.5$, and $\mathbf{B}$, ammonium molybdate, $\mathrm{pH}$ 7.0. Bar represents $150 \mathrm{~nm}$. 
was RNA. Absorption of the RNA to oligo-dT indicated that the two RNA species are polyadenylated. Using the MCID image analysis system (version 1.2; Imaging Research Inc., St. Catharines, Ontario, Canada) and a 0.24- to 9.5-kb RNA ladder (Gibco BRL, Life Technologies Ltd., Baisley, Scotland) as a molecular size marker, the two RNAs were estimated to be 6,700 and 7,700 nucleotides (nt) in size (Fig. 6).

Analysis of the cloned viral sequence. Several cDNA clones containing an insert of about 1,300 nt were obtained and appeared similar by restriction mapping. One of these clones was selected for further analysis in Northern blots. In these tests, both viral RNAs hybridized to the labeled cDNA probe, but the hybridization signal from RNA2 was significantly stronger than from RNA1, even considering that, in the viral RNA extracts, the level of RNA2 was higher than the level of RNA1 (Fig. 6A and B). A similar result was obtained using a cDNA probe containing nucleotides complementary to nucleotides 1,074 to 623 from the $3^{\prime}$ end of the viral RNA (data not shown). These results indicate that the selected clone originated from the $3^{\prime}$ terminus of RNA2 and that the $3^{\prime}$ terminal sequences of the two viral RNAs show some level of homology. Homologies exist also in the $3^{\prime}$ terminal regions of the RNA1 and RNA2 species of CLRV (24), BLMV (3), and ToRSV (22) nepoviruses.

The same virus clone was sequenced from both ends using M13/pUC reverse sequencing primer and sequencing primer, or $\mathrm{T} 7$ and T3 primers, annealing in the vector. The central part of the clone was sequenced in two reactions in opposite directions by using an oligonucleotide primer designed to anneal in position 300 upstream from the poly(A) tail and by terminal sequencing of a subclone (nucleotides 1 to 1,075 ). The sequence was compiled with the Fragment Assembly program (FASTA) of the Wisconsin Sequence Analysis Package (Genetics Computer Group) and is shown in Figure 7. Comparison of this sequence with the EMBL sequence database by the FASTA program detected a stretch of $239 \mathrm{nt}$, in positions 13 to 251 of the sequenced fragment, that

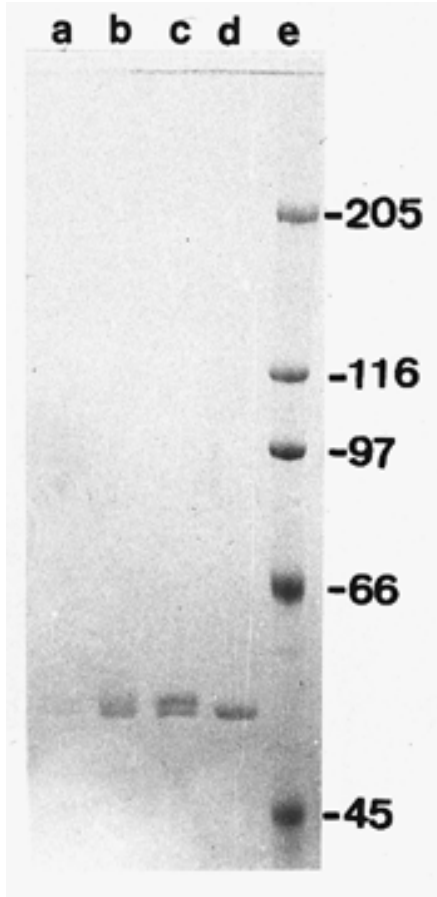

Fig. 5. Sodium dodecyl sulfate-polyacrylamide gel electrophoresis analysis in $10 \%$ gels of four protein preparations from purified black currant reversion associated virus particles showing the two protein bands of 55 and $54 \mathrm{kDa}$ usually observed and, in lane d, the single band of $54 \mathrm{kDa}$ observed in one preparation. Molecular weight marker, in lane e, is high molecular weight standard mixture SDS-6H (Sigma Chemical Co., St. Louis). showed $66 \%$ identity to the sequence of the $3^{\prime}$ terminal regions (nucleotides 1,206 to 1,438 from the $3^{\prime}$ end) of RNA1 and RNA2 of CLRV, isolate I2 (24) (data not shown). The same site in the BRAV sequence also showed similarity to the walnut isolate of CLRV. No homology was detected to the $3^{\prime}$ terminal $1,000 \mathrm{nt}$ of CLRV RNAs, even though a region of about $8003^{\prime}$ terminal nucleotides is very highly conserved between CLRV isolates I2 and R (rhubarb) (24) and is sufficiently conserved in CLRV isolates from poplar, beech, and walnut to hybridize to $3^{\prime}$ terminal probes (1,000 nt) of isolates I2 and R in a dot blot analysis (24).

Within the $2003^{\prime}$ terminal nucleotides of BRAV, significant levels of similarities were found also to the $3^{\prime}$ terminal sequences of BLMV and RpRSV nepoviruses, and of RNA2 of cowpea mosaic (CPMV) and red clover mottle (RCMV) comoviruses. The 3' regions of these five viruses also contain a conserved motif of 17 nt (with a mismatch of two nucleotides in BRAV RNA2) that also occurs in the nepoviruses ArMV, grapevine chrome mosaic (GCMV), GFLV, and TBRV (3,25) (Fig. 8).

IC-RT-PCR detection of BRAV in Ribes plants and gall mites and its association with black currant reversion disease. With the 'hot-start' IC-RT-PCR protocol, the 210-nt 3' terminal fragment of BRAV RNA was efficiently amplified and detected from purified virion preparations, BRAV-infected $C$. quinoa, and the black currant plants from which the virus had been first isolated. The PCR fragment was not detected from healthy plants of C. quinoa or black currant plants. The virus-specific 210-nt PCR cDNA fragment was also detected in leaves of 12 field-grown black currant plants affected by two isolates of the $\mathrm{R}$ form of reversion disease, obtained originally from ARC-IH, Piikkiö (southwest Finland) and Parikkala (eastern Finland) (4) (Fig. 9A and Table 1). It was also detected in samples of 50 mites (C. ribis) picked out of galled buds from these black currant plants (Fig. 9A,
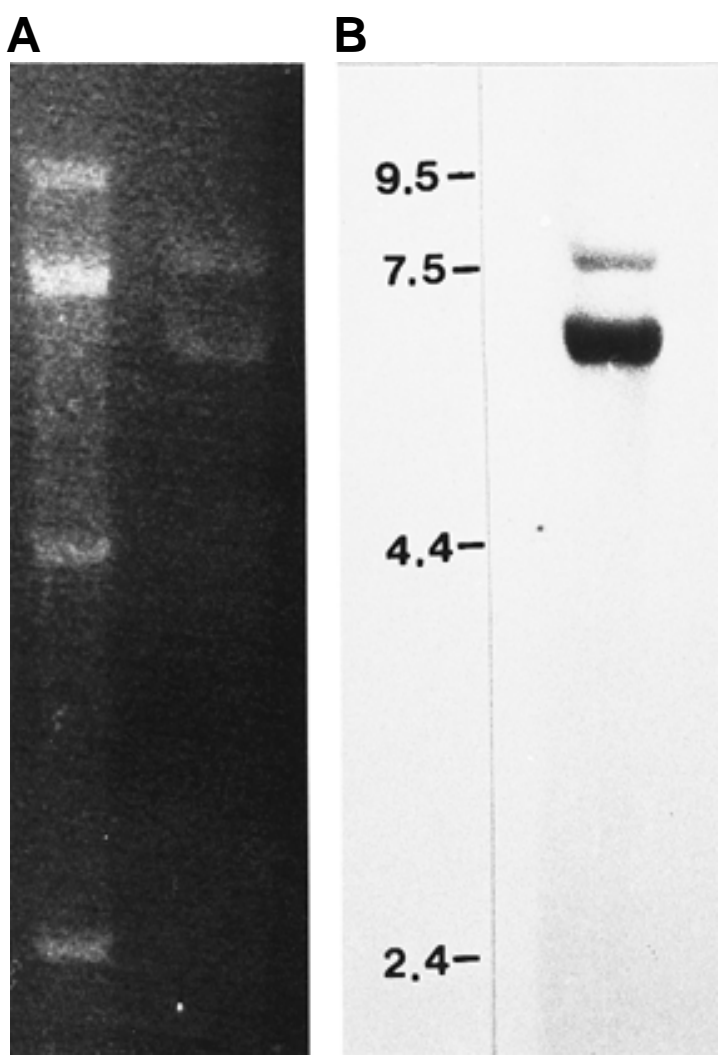

Fig. 6. A, Agarose gel electrophoresis of black currant reversion associated virus (BRAV) RNAs stained with ethidium bromide and viewed under UV light. B, Northern blot of total BRAV RNA probed with the $3^{\prime}$ terminal cDNA clone. The molecular size marker in nucleotides is the $0.24-$ to $9.5-\mathrm{kb}$ RNA molecular size ladder (Gibco BRL, Life Technologies Ltd., Baisley, Scotland) stained with ethidium bromide. 
lanes 11 and 12). However, in some of these assays, only a low level of amplification of the 210-nt PCR product was detected (Fig. 9A, lanes 5, 6, and 9), suggesting that the virus concentration and its distribution in plants is uneven. Also, a low level of the amplified viral sequences was detected in samples of 50 mites (lanes 11 and 12), but the amplification was much stronger when larger (uncounted) numbers of mites were tested (data not shown).

In further studies, IC-RT-PCR analysis of laboratory cultures of Ribes plants from Scotland, infected or uninfected with the reversion agent or affected with known virus or virus-like diseases of Ribes, detected the 210-nt PCR product only in assays of plants known to be infected with the reversion agent ( $\mathrm{R}$ and $\mathrm{E}$ forms) (Fig. 9B and Table 1). It was not detected in assays of virus-tested healthy plants of six black currant cultivars (Fig. 9B and Table 1) or in black currant plants naturally infected with, or graft inoculated with, ArMV or the agents of black currant yellows, infectious variegation, and gooseberry veinbanding diseases (Table 1). Furthermore, the 210-nt product was not detected following ICRT-PCR of nucleic acid extracts of $C$. quinoa plants infected either with ArMV (two isolates), RpRSV (Scottish strain), or SLRSV (Scottish strain) nepoviruses (Table 1).

The 210-nt product was also detected in tests on three plants of 'Ben Nevis' black currant and in two plants each of the cvs. Ben Lomond and Ben More that had been infested experimentally 4 years previously with gall mites from a black currant bush showing symptoms of the $\mathrm{E}$ form of reversion disease and maintained subsequently in a heated glasshouse (Table 1). However, only the three 'Ben Nevis' plants showed distinct symptoms of reversion disease, and these became evident only in the fourth year after infestation with the mites. Clearly, therefore, BRAV was transmitted by the mites to all seven plants and they also transmitted the reversion agent at least to the 'Ben Nevis' plants. The absence of reversion symptoms in the other two cultivars may possibly be due to the known delay in expression of reversion symptoms after inoculation (1) and that this delay was accentuated by the low amount of inoculum used (mites compared with graft inoculation) and by the warm conditions under which the plants were subsequently maintained.

The 210-nt product was also detected by IC-RT-PCR in two samples of reverted black currant from New Zealand, whether they showed mild or severe symptoms, but it was not detected in healthy plants (Fig. 9C and Table 1).

During the summer of 1995, 55 field samples of black currant, collected from various locations in southern Finland, were tested for BRAV by IC-RT-PCR. Of these, 41 showed some putative reversion symptoms varying from mild symptoms to strong uniform symptoms. From these, the BRAV-specific, 210-nt band was detected in 34 samples. Of the 14 symptomless bushes tested, 13 were negative for BRAV and one gave a weak positive detection. In the following summer (1996), several shoots of this latter bush showed clear symptoms of reversion (data not shown).

\section{DISCUSSION}

Reversion is the most important disease of black currant crops worldwide and is particularly widespread in Eastern and Central

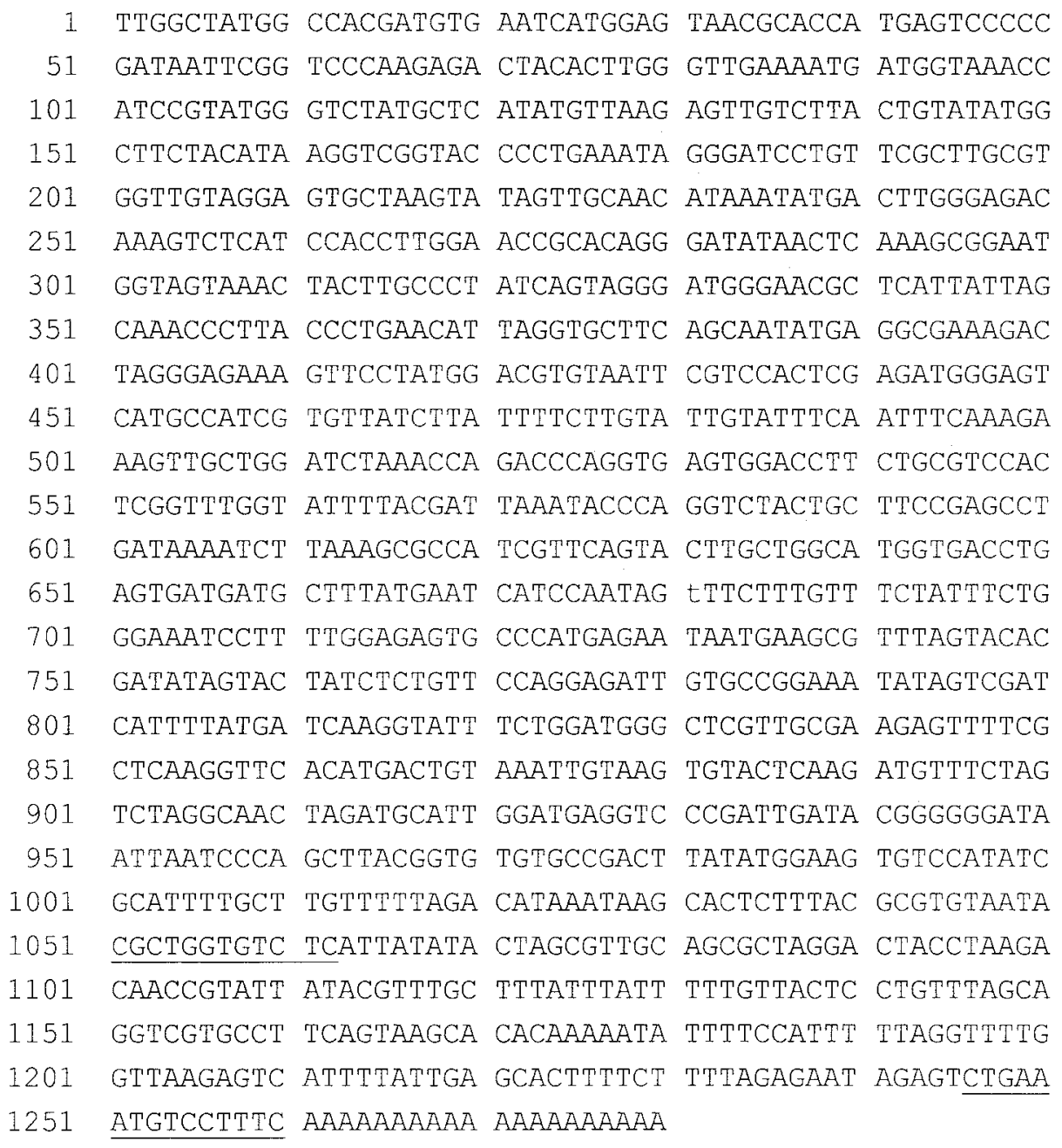

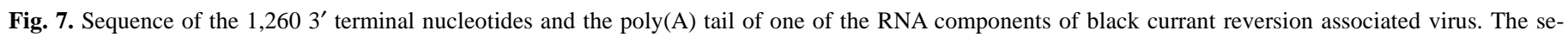
quences used as oligonucleotide primers for polymerase chain reaction are underlined. 
Europe and Russia, and in some parts of the United Kingdom and Scandinavia $(1,12,26$; J. Spak and B. Zawadska, personal communication; A. T. Jones, A. Lemmetty, and K. Lehto, unpublished data); in recent years, it has become a serious problem in New Zealand (A. T. Jones, unpublished data). A form of the disease (R) present in Eastern and Central Europe, Russia, and Scandinavia is much more severe in plants than the common E form, but the progression of the disease in plants and crops is similar with each of these forms of the disease (12).

Because of the seriousness of the disease problem, attempts to identify the causal agent of reversion have been made by several workers over many decades, but without success. Approaches to

\begin{tabular}{|c|c|c|c|c|}
\hline BRAV & TGCCTTCAGT & AAGCACACAA AAATATTTTC & CATTTTTAGG & .65 nt.. poly-A \\
\hline BIMV & TGCCTTCAGT & AA GCACACAA AAAGATTTCG & САТТTТТСТT & 41 nt. . \\
\hline RpRSV & TGCCTTTAGC & AAGCACACAA $\triangle \overline{A A A T} A T G C A T$ & TTGTTTTTGT & poly-A \\
\hline RCMV & AACCTTCAGC & AAGTTCACAA AAAGATTTTC & CTTTTGTGTG & $6 \mathrm{nt}$ \\
\hline CPMV & TCCCTTCAGC & AA GGACACAA AAAGATTTTA & ATTTTATT & pol \\
\hline & & TTGGACGCAA AAAGATTTTA & PTTTT & nt. \\
\hline & & TT GGACGCAA AAAGATTTTS & ССТTТСТTТT & $r-\mathrm{A}$ \\
\hline & & ITGGACACAA AAAGATTTTA & ТАТТТСТТАА & nt. \\
\hline & & TT GGACACAA AAAGATTTTC & & nt. \\
\hline
\end{tabular}

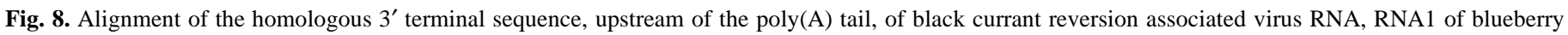

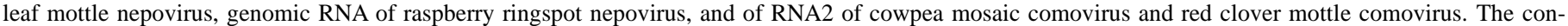

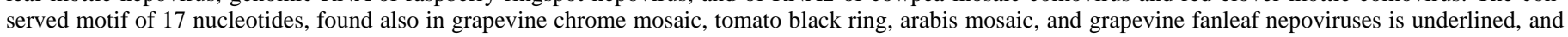
the conserved nucleotides of the motif are in italics. The distance to poly(A) tail from each sequence is indicated.
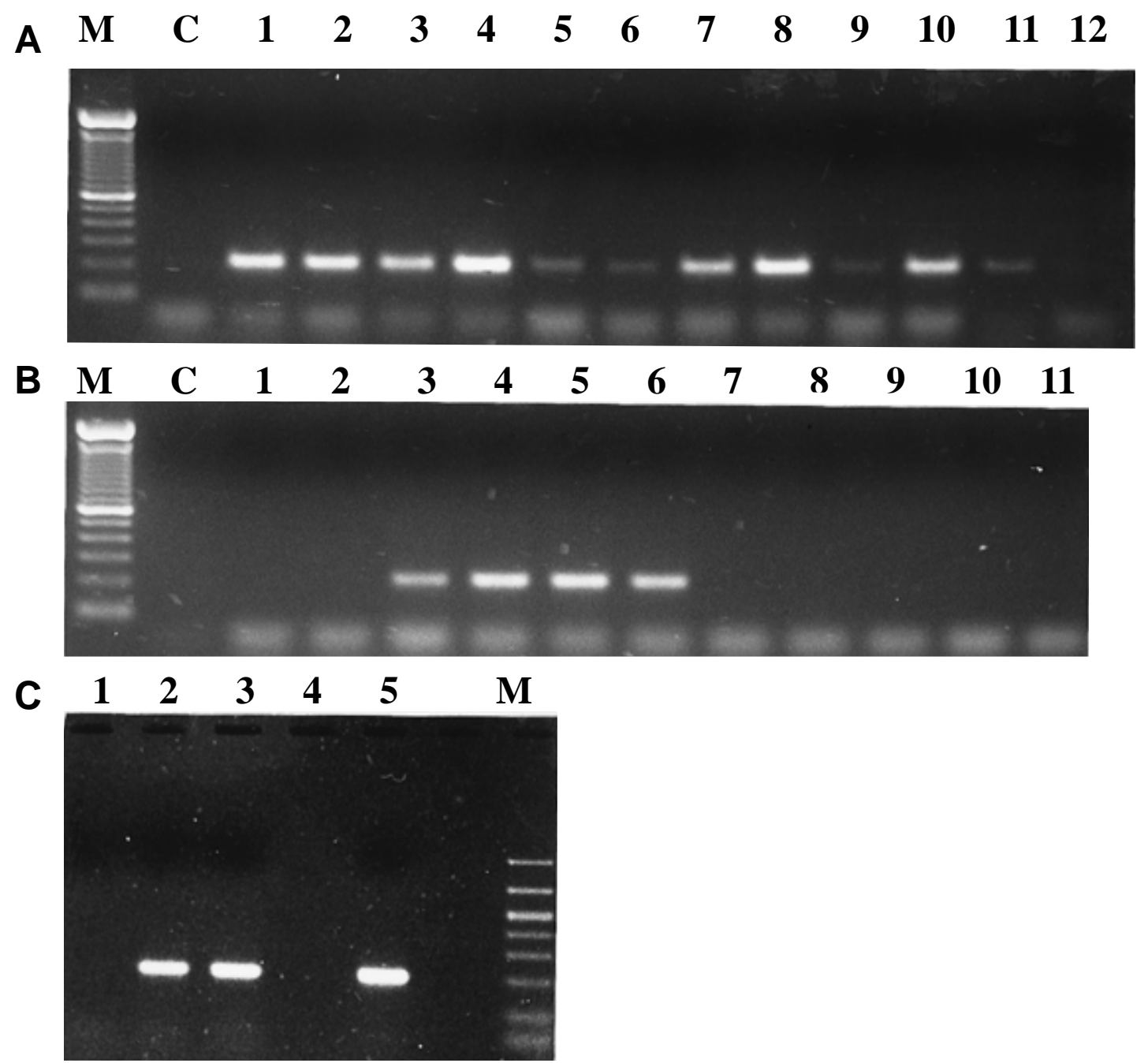

Fig. 9. Immunocapture reverse transcriptase polymerase chain reaction (IC-RT-PCR) amplification of the 210-bp cDNA fragment of black currant reversion associated virus RNA from nucleic acid extracts from plants or mites. In the gels in A and B, lane 'M' contains a 100-bp DNA ladder (Gibco BRL) and, in each gel, lane ' $\mathrm{C}$ ' contains material following IC-RT-PCR of healthy black currant. Extracts were from A, Samples from Finland: individual black currant bushes affected with the R form of reversion disease obtained initially from ARC-IH, Piikkiö (lanes 1 to 5) and Parikkala (lanes 6 to 10); and groups of 50 gall mites from galls on affected black currant plants from ARC-IH, Piikkiö (lane 11) and Parikkala (lane 12). Bands in lanes 6, 9, and 12 were very faint and have not reproduced well in the figure. B, Samples from Scotland: healthy plants of the black currant cultivars Ben Alder (lanes 1 and 7), Ben Lomond (lanes 2 and 11), Ben Nevis (lane 8), Ben Tirran (lane 9), and Ben Sarek (lane 10) and unnamed cultivars affected with the R (lanes 3 and 4) and E (lanes 5 and 6 ) forms of reversion disease. C, Samples of the black currant cultivar Silvergiertes Schwarze from New Zealand: lane 1, healthy plant; lanes 2 and 3, plants showing mild and severe reversion symptoms, respectively; lanes 4 and 5, control samples of healthy and reverted black currant from Finland, respectively; and lane M, a 50- to 1,000-bp DNA marker (FMC BioProducts, Rockland, ME). 
identify the agent by electron microscopy of reverted plant tissue (I. M. Roberts and A. T. Jones, unpublished data) and of gall mite vectors on such plants (21), and by analysis of dsRNA in plants (S. Cox, A. T. Jones, and M. A. Mayo, unpublished data) have also been unsuccessful. Our finding of a newly described virus in reverted plants, its mechanical transmission to herbaceous test plants, and its close association with the two forms of reversion disease is, therefore, an important step forward in understanding the etiology of the disease. However, in view of the failure of previous attempts by workers to detect a sap-transmissible virus associated with reversion disease, the possible reasons for our success require some comment.

Firstly, BRAV was isolated from reverted black currant cuttings showing pronounced line patterns and ringspots only once, despite many other attempts to repeat this. The virus is, therefore, very difficult to isolate from Ribes tissue, due possibly to its very low concentration and erratic distribution in plants and its rapid inactivation by phenolic compounds present in leaves of these woody plants. Our data on the in vitro properties of BRAV in herbaceous plant sap would indicate its relative instability. Possibly, the sensitivity to the reversion agent of the SCRI black currant selection P9/5/1 studied, the use of the severe $\mathrm{R}$ form of the disease, and the physiological conditions associated with young actively growing cuttings whilst rooting combined fortuitously to produced the conditions suitable for our single transmission of BRAV to herbaceous plants. In this connection, it is noteworthy that Atroshchenko (2) reported that foliar line patterns on reversion affected black currant seedlings were more pronounced during, and shortly after, rooting. The combination of these different factors may explain the failure of earlier attempts by workers to detect this virus.

The particle morphology and size, and the number and sizes of the coat protein subunits and RNA species of BRAV suggest that it is very similar to nepoviruses $(15,16,17)$. Furthermore, in the sedimentation profile of its particles in sucrose density gradients and in the size of its RNA2 (6,700 nt) and the possible homology between the 3' ends of its RNAs, it resembles most closely those viruses in the proposed subgroup 3 of nepoviruses, such as CLRV and BLMV $(3,15,16,17,20$; A. T. Jones, unpublished data). This is supported by the fact that short stretches of some RNA sequence homology was detected between BRAV and CLRV. It is also noteworthy that immediately upstream of the poly(A) tail of BRAV RNA there is a domain of $17 \mathrm{nt}$, with only two nucleotide mismatch, that is conserved between BRAV and some nepoviruses in the proposed subgroup 1 (ArMV, GFLV, and RpRSV), subgroup 2 (TBRV and GCMV) (25), and subgroup 3 (BLMV) (3), and in the RNA2 species of CPMV and RCMV comoviruses (Fig. 8). Nevertheless, BRAV is serologically unrelated to CLRV and several of its variants tested, BLMV, and eight other viruses that can be placed in subgroup 3 of nepoviruses (AYRSV, CGMV, ChYMV, GBLV, HLRSV, LALV, PRMV, and ToRSV) (15). Moreover, we have also shown that BRAV is unrelated to any of the other sap-transmissible viruses reported from Ribes species $(1,12$, 13) and is, therefore, a newly described virus from Ribes.

The isolation and characterization of this virus have provided the materials for its detection in plants by IC-RT-PCR, and this technique has given the necessary sensitivity and reliability to assay for BRAV in a wide range of Ribes plants infected with different viruses or virus-like agents and to draw some conclusions on its possible involvement, or otherwise, in known diseases of Ribes. Using this detection system, we have demonstrated that BRAV is very closely and specifically associated with black currant reversion disease. We have detected BRAV in 23 black currant plants affected with either of the two forms of reversion and originating from widely different geographical regions of Finland, Scotland, and New Zealand. BRAV was also detected in gall mite vectors collected from reversion-affected black currant and was transmitted by such mites experimentally to originally healthy black currant plants that were grown subsequently under protected conditions in a glasshouse. Some of these mite-inoculated plants later developed reversion disease. Of 41 field samples showing putative symptoms of reversion disease, BRAV was detected in 34. Of equal importance is that BRAV was not detected in the 27 samples of healthy plants, plants infected with the agents of other virus-like diseases of Ribes, or with

TABLE 1. Results of immunocapture reverse transcriptase polymerase chain reaction (IC-RT-PCR) to detect black currant reversion associated virus (BRAV) in samples of black currant and Chenopodium quinoa plants that were either healthy or infected with known virus or virus-like disease of Ribes

\begin{tabular}{|c|c|c|c|c|}
\hline Location & Species and cultivar & Infection status & $\begin{array}{l}\text { No. of plants/ } \\
\text { no. of samples }\end{array}$ & $\begin{array}{c}\text { PCR result } \\
\text { (no. of positives) }\end{array}$ \\
\hline $\mathrm{ARC}^{\mathrm{a}}$ (Finland) & $\begin{array}{l}\text { Black currant } \\
\text { Unknown } \\
\text { Unknown } \\
\text { Öjebyn }\end{array}$ & $\begin{array}{l}\text { Reversion, R form }{ }^{\mathrm{b}} \\
\text { Isolate 'Piikkiö' of reversion } \\
\text { Isolate 'Parikkala' of reversion } \\
\text { Healthy }\end{array}$ & $\begin{array}{l}6 / 6 \\
6 / 6 \\
2 / 6\end{array}$ & $\begin{array}{l}6 \\
6 \\
0\end{array}$ \\
\hline $\mathrm{SCRI}^{\mathrm{c}}$ (Scotland) & $\begin{array}{l}\text { Black currant } \\
\text { Unknown } \\
\text { Unknown } \\
\text { Ben More } \\
\text { Amos Black } \\
\text { Ben Alder } \\
\text { Öjebyn } \\
\text { Öjebyn } \\
\text { Ben Nevis } \\
\text { Ben Lomond } \\
\text { Ben Nevis } \\
\text { Ben Lomond } \\
\text { Ben More } \\
\text { Chenopodium quinoa }\end{array}$ & $\begin{array}{l}\text { Healthy } \\
\text { Reversion, E form }{ }^{\mathrm{b}} \\
\text { Reversion, R form } \\
\text { Reversion, R form } \\
\text { Reversion, R form } \\
\text { Yellows disease } \\
\text { Yellows disease } \\
\text { Infectious variegation } \\
\text { Gooseberry veinbanding } \\
\text { Arabis mosaic virus } \\
\text { Inoculated with mites from reverted plants, reversion symptoms } \\
\text { Inoculated with mites from reverted plants, no symptoms } \\
\text { Inoculated with mites from reverted plants, no symptoms } \\
\text { Strawberry latent ringspot virus } \\
\text { Arabis mosaic virus } \\
\text { Raspberry ringspot virus } \\
\text { Healthy }\end{array}$ & $\begin{array}{l}8 / 8 \\
2 / 2 \\
2 / 2 \\
1 / 1 \\
1 / 1 \\
1 / 1 \\
1 / 1 \\
1 / 1 \\
2 / 2 \\
2 / 2 \\
3 / 3 \\
2 / 2 \\
2 / 2 \\
1 / 1 \\
2 / 2 \\
1 / 1 \\
1 / 1\end{array}$ & $\begin{array}{l}0 \\
2 \\
2 \\
1 \\
1 \\
0 \\
0 \\
0 \\
0 \\
0 \\
3 \\
2 \\
2 \\
0 \\
0 \\
0 \\
0\end{array}$ \\
\hline HFRI $^{\mathrm{d}}$ (New Zealand) & $\begin{array}{l}\text { Black currant } \\
\text { Silvergiertes Schwarze }\end{array}$ & $\begin{array}{l}\text { Reversion, E form } \\
\text { Healthy }\end{array}$ & $\begin{array}{l}2 / 2 \\
1 / 1\end{array}$ & $\begin{array}{l}2 \\
0\end{array}$ \\
\hline
\end{tabular}

${ }^{a}$ ARC $=$ Agricultural Research Centre, Jokioinen, Finland.

${ }^{\mathrm{b}}$ Reversion form $\mathrm{R}=$ more severe, Russian, and $\mathrm{E}=$ common, European.

${ }^{c}$ SCRI = Scottish Crop Research Institute, Invergowrie, Scotland.

${ }^{\mathrm{d}}$ HFRI $=$ The Horticultural and Food Research Institute of New Zealand Ltd., Auckland. 
known Ribes viruses including several nepoviruses. Of 14 field samples showing no symptoms of reversion, BRAV was detected in only one plant that, in the following year, showed clear symptoms of reversion.

The evidence for the association of BRAV with reversion disease is, therefore, very strong, but it is not complete, supporting the use of its tentative name. Thus, BRAV was not detected in seven field samples showing putative (mild) symptoms of reversion and was detected in four black currant plants that were infested with gall mites from reverted plants that have not, as yet, developed obvious symptoms of reversion disease. The failure to detect BRAV in field plants with possible reversion symptoms may be due to the misdiagnosis of the symptoms or to the known slow systemic spread and erratic distribution of the disease agent in black currant bushes $(1,12)$. Similarly, the lack of symptoms in the BRAV-infected plants infested with mites from reverted plants may possibly be due to the slow and erratic development of symptoms, especially under the warmer conditions of the glasshouse, and also to the lower inoculum load (mites compared with graft inoculation). This is supported, to some extent, by the very slow development (4 years) of reversion symptoms in cv. Ben Nevis, the other cultivar infected with BRAV by mites in this experiment.

Unequivocal evidence that BRAV is the causal agent of reversion disease depends on the ability to fulfill Koch's postulates by reinfecting healthy black currant with the purified virus and reproducing the disease. Presently, technical difficulties prevent us from doing this, because Ribes plants are very difficult to infect with virus by mechanical inoculation due, presumably, to the high levels of tannins and polyphenols in leaves. Furthermore, the development of reversion symptoms in inoculated black currant plants may take more than 2 years (1). Until more definitive information becomes available, therefore, we propose the continued use of the name black currant reversion associated virus.

Despite the absence of this final proof, our finding of a very close association of BRAV with reversion disease and the development of an IC-RT-PCR protocol to detect BRAV in Ribes tissue are major steps forward in the possible identification of the causal agent of reversion and a rapid means of diagnosing it in plants. They also provide a means to study in more detail the relationship of BRAV with its plant host and mite vector.

Finally, in addition to showing from its physicochemical properties that BRAV has strong affinities with nepoviruses, especially those in subgroup $3(15,16)$, we have also demonstrated that BRAV is transmitted by the black currant gall mite. If the remaining sequence of the RNAs of BRAV confirm its status as a nepovirus, then it raises interesting questions regarding the transmission of the majority (>60\%) of the 38 known nepoviruses and tentative nepoviruses that have no known vector (17). In the light of our work with BRAV, it may be opportune to examine the possibility that mites may also act as vectors for some of those nepoviruses for which the mode of transmission is not known.

\section{ACKNOWLEDGMENTS}

Research at the University of Turku was funded by grants from the Finnish Ministry of Education and the University of Turku. Research at the Scottish Crop Research Institute (SCRI) was aided by a grant from the Scottish Office Agriculture, Environment and Fisheries Department (SOAEFD). Nonindigenous viruses were studied at SCRI under the conditions of a license from SOAEFD. We thank S. Räsänen and J. Ahlholm for technical assistance and UK Blackcurrant Growers Research and Development Fund for a grant for A. T. Jones to visit Finland. We also thank I. M. Roberts and G. Duncan for examination of virus preparations in the electron microscope, and A. A. Brunt, D. Gonsalves, R. Koenig, G. Martelli, and D. Ramsdell for gifts of virus antisera and viruses and G. Wood for supplying black currant material from New Zealand.

\section{LITERATURE CITED}

1. Adams, A. N., and Thresh, J. M. 1987. Reversion of blackcurrant. Pages 133-136 in: Virus Diseases of Small Fruits. R. H. Converse, ed. U.S. Dep. Agric. Agric. Handb. 631.

2. Atroshchenko, G. P. 1992. A new diagnostic character of reversion. Zashch. Rast. (Mosc.) 7:52.

3. Bacher, J. W., Warkentin, D., Ramsdell, D., and Hancock, J. F. 1994. Sequence analysis of the 3' termini of RNA1 and RNA2 of blueberry leaf mottle virus. Virus Res. 33:145-156.

4. Bremer, K. 1983. Viral diseases occurring on Ribes species in Finland. Ann. Agric. Fenn. 22:104-109.

5. Bremer, K., and Heikinheimo, O. 1980. Problems of the reversion disease of Ribes in Finland. Acta Hortic. 95:87-91.

6. Demangeat, G., Hemmer, O., Reinbolt, J., Mayo, M. A., and Fritsch, C. 1992. Virus-specific proteins in cells infected with tomato black ring nepovirus: Evidence for proteolytic processing in vivo. J. Gen. Virol. 73:1609-1614.

7. Erlich, H. A., Gelfand, D., and Sninsky, J. J. 1991. Recent advances in the polymerase chain reaction. Science 252:1643-1651.

8. Frison, E. A., and Stace-Smith, R. 1992. Cross-reacting and heterospecific monoclonal anti-bodies produced against arabis mosaic virus. J. Gen. Virol. 73:2525-2530.

9. Jacob, H. 1976. Investigations on symptomatology, transmission, etiology and host specificity of blackcurrant reversion virus. Acta Hortic. 66:99-104.

10. Jones, A. T. 1976. Serological specificity of isolates of cherry leaf roll virus from different natural hosts. Poljopr. Znan. Smotra 39:527-532.

11. Jones, A. T. 1992. Appendix I. Recommended indexing procedures for detecting viruses, viroids, mycoplasma- and rickettsia-like organisms and virus-like diseases in small fruit crops: Currants and gooseberries (Ribes). Acta Hortic. 308:151-154.

12. Jones, A. T. 1993. Defining the problem: Reversion disease and eriophyid mite vectors in Europe. Pages 1-4 in: Proceedings of the Risk Assessment Workshop. USDA-ARS, Germplasm Repository, Corvallis, OR.

13. Jones, A. T., and McGavin, W. J. 1996. A damaging outbreak of arabis mosaic nepovirus in blackcurrant, the occurrence of other nepoviruses in Ribes species, and the demonstration that alfalfa mosaic virus is the cause of interveinal white mosaic in blackcurrant. Ann. Appl. Biol. 129:47-55.

14. Laemmli, U. K. 1970. Cleavage of structural proteins during the assembly of the head of bacteriophage T4. Nature (Lond.) 227:680-685.

15. Mayo, M. A., and Robinson, D. J. 1996. Nepoviruses: Molecular biology and replication. Pages 139-186 in: The Plant Viruses, Vol. 5: Polyhedral Virions and Bipartite RNA Genomes. B. D. Harrison and A. F. Murant, eds. Plenum Press, New York.

16. Murant, A. F. 1981. Nepoviruses. Pages 197-238 in: Handbook of Plant Virus Infections Comparative Diagnosis. E. Kurstak, ed. Elsevier/NorthHolland, Amsterdam.

17. Murant, A. F., Jones, A. T., Martelli, G. P., and Stace-Smith, R. 1996. Nepoviruses: General properties, diseases, and virus identification. Pages 99-137 in: The Plant Viruses, Vol. 5: Polyhedral Virions and Bipartite RNA Genomes. B. D. Harrison and A. F. Murant, eds. Plenum Press, New York.

18. Nolasco, G., de Blas, C., Torres, V., and Ponz, F. 1993. A method combining immunocapture and PCR amplification in a microtitre plate for detection of plant viruses and subviral pathogens. J. Virol. Methods 45:201-218.

19. Protsenko, A. E., and Surgucheva, N. A. 1972. Mycoplasma etiology of reversion disease of blackcurrant. (In Russian, with English summary.) Skh. Biol. 9:80-83.

20. Ramsdell, D. C., and Stace-Smith, R. 1980. Blueberry leaf mottle, a new disease of highbush blueberry. Acta Hortic. 95:37-48.

21. Roberts, I. M., Jones, A. T., and Amrine, J. W. 1994. Ultrastructure of the blackcurrant gall mite, Cecidophyopsis ribis (Acari: Eriophyidae), the vector of the agent of reversion disease. Ann. Appl. Biol. 125:447-455.

22. Rott, M. E., Rochon, D. M., and Tremaine, J. H. 1988. A 1.9 kilobase homology in the $3^{\prime}$ terminal regions of RNA-1 and RNA-2 of tomato ringspot virus. J. Gen. Virol. 69:745-750.

23. Sambrook, J., Fritsch, E. F., and Maniatis, T. 1989. Molecular Cloning: A Laboratory Manual, 2nd ed. Cold Spring Harbor Laboratory, Cold Spring Harbor, New York.

24. Scott, N. W., Cooper, J. I., Liu, Y. Y., and Hellen, C. U. T. 1992. A $1.5 \mathrm{~kb}$ sequence homology in the 3 -terminal regions of RNA-1 and RNA-2 of a birch isolate of cherry leafroll nepovirus is also present, in part, in a rhubarb isolate. J. Gen. Virol. 73:481-485.

25. Serghini, M. A., Fuchs, M., Pinck, M., Reinbolt, J., Walter, B., and Pinck, L. 1990. RNA2 of grapevine fanleaf virus: Sequence analysis and coat protein cistron location. J. Gen. Virol. 71:1433-1441.

26. Thomsen, A., Nielsen, S. L., and Rasmussen, A. N. 1991. Ribbesvind ogsolbaerknopgalmider. (In Danish.) Havebrug Grøn Viden 65:1-4. 